Indonesian Journal of EFL and Linguistics

Vol. 4 No. 2, 2019

eISSN: 2503-4197, pISSN: 2527-5070

www. indonesian-efl-journal.org

\title{
Developing English Materials Using ESP Approach for al-Qur'an and Tafsir Study Program Students
}

\author{
Nurliana \\ Institut Agama Islam Negeri Palangka Raya \\ email: nurliana@iain-palangkaraya.ac.id
}

\begin{abstract}
:
This study aimed at developing English materials using ESP approach for the first semester students of al-Qur'an and Tafsir Study Program at IAIN Palangka Raya in academic year 2018/2019. In this study, the model of materials development proposed by Sugiyono (2013:298) was adapted with the following steps: need assessment, reference of the research, development of English materials using ESP approach, expert validation, revision, try-out of the materials, revision, and final product. The instruments used consisted of questionnaire, observation, and interview. The data gathered was analyzed and described qualitatively. The students' need based on the result of questionnaire was English materials using ESP approach. Considering that result, the English materials using ESP approach were developed and tried in 8 meetings. The data collected from try-out showed that the developed materials were applicable to the teaching-learning process and appropriate with the students' need. Furthermore, the students responded positively toward the developed materials. They were active, motivated, and enthusiastic in doing the activities of the developed materials. English materials using ESP approach in the form of a textbook divided into eight units were the product of this study. The topics were Prayer, Fasting, Zakat, Muamalat, Food in Islamic Law, Property Right in Islamic Law, Inheritance in Islamic Law, and al-Qur'an and Science. The textbook was also supplemented with a list of vocabularies section, a list of regular verbs section, and a list of irregular verbs section.
\end{abstract}

Keywords: EFL, ELT, ESP, learning materials, materials development

Indonesian Journal of EFL and Linguistics, 4(2), 2019 
Nurliana

\section{INTRODUCTION}

ESP approach refers to the English teaching-learning process in specific domains of use. Therefore, ESP approach gives a lot of attention to the particular communicative needs and practices of the specific groups (Hyland, 2019:2). Since English keeps dominating as the lingua franca in education, media, and other fields, it leads to the increase of ESP approach demand, especially in EFL countries. More and more universities all over the world offer ESP approach to meet students' need for their future career. ESP approach is considered to be more effective in increasing students' motivation in learning English since it relates to the students' field of study (Bracaj, 2014:40-41). ESP gives more attention to certain fields of study, such as Islamic studies, nursing, engineering, and so forth. Students learning English in English for General Purposes (EGP) approach are different from students learning English in English for Specific Purposes (ESP) approach. The students learn English in EGP approach for the mastery of the English language to pass English examination. In contrast, the students learn English in ESP approach to carry out a specific role, for examples, the role as a foreign student in a university in which English used as a medium instruction, doctor, flight attendant, or mechanic (Richards, 2001:28).

One of the key components should be considered to implement ESP approach is materials. Tomlinson (2012: 143-144) defines materials as anything used in the language teaching-learning process which includes textbooks, websites, videos, games, flashcards, grades readers, and also interactions of mobile phone. In Indonesia English is classified as EFL. Students in EFL contexts are different from those in ESL context. Lee (2015:147) argued that students in EFL context chiefly depend on English materials and instructions given by teachers. Thus, English teachers should be facilitated to give students efficient instructions. In addition, students should be encouraged to improve their proficiency in English. Furthermore, materials used in ESP approach are different from materials used in EGP approach. The materials used in ESP approach focus on the students' specific field of study. In contrast, the materials used in EGP approach focus on the basic knowledge and skills of English. In Indonesia, more and more study programs of the higher institutions demand lecturers to implement ESP approach in the English teachinglearning process. In this case, lecturers and researchers are challenged to develop materials using ESP approach appropriate with students' need.

English is one of the compulsory courses in al-Qur'an and Tafsir Study Program at IAIN Palangka Raya. Three credits of English course are offered in the first semester. This course comprises sixteen meetings for one semester in which the time allocation for each meeting is 150 minutes. English in al-Qur'an and Tafsir Study Program at IAIN Palangka Raya could be classified as ESP. The target competencies of the English course were that the students were able to comprehend the vocabularies and structure of English texts related to the verses of al-Qur'an. In 
addition, the students were able to read English texts, listen to English texts, write English texts, and speak in English related to the verses of al-Qur'an. One of the factors of the success in the teaching-learning process is the materials used. However, the preliminary observation result showed that the English teachinglearning process in al-Qur'an and Tafsir Study Program at IAIN Palangka Raya has the problem related to the materials used. In this case, most of the materials available in the campus libraries and nearby bookstores were general English textbooks and a few English for Islamic Studies textbooks. The ESP textbooks, especially for al-Qur'an and Tafsir Study Program were not available. Consequently, this condition made the English lecturer more depended on the commercial materials in the form of English for Islamic Studies textbooks in the teaching-learning process. However, since the textbooks used were not designed based on the students' need and not designed especially for al-Qur'an and Tafsir Study Program students, in the English teaching-learning process, it seemed that the contents of the textbooks used were difficult for the first semester students to understand. If this condition was neglected and continued to occur, it could lead to the failure of achieving the target competencies of the English course. Furthermore, based on the result of the interview with some students of al-Qur'an and Tafsir Study Program in academic year 2018/2019, it was found that English materials related to their specialties or their future career were needed since those materials would make them more interested and more motivated in learning English. Moreover, it would also be very useful for them in the future to do their work related to al-Qur'an and Tafsir field. Concerning the background of the study stated previously, it was necessary to develop the appropriate English instructional materials using ESP approach for alQur'an and Tafsir Study Program students at IAIN Palangka Raya in academic year $2018 / 2019$.

There were some studies relevant to this study. Rizal (2017) developed ESP reading comprehension instructional materials through schemata theory approach for Islamic Education Study Program students of Tarbiyah Faculty at IAIN Bengkulu. The product of his study was ESP materials related to Islamic educational studies. The topics of the materials were Islamic Law, Islamic Educational History, Aqidah Akhlak, and al-Qur'an and Hadith. The result of his study indicated that the students responded positively toward the developed ESP materials. The developed ESP materials were effective to improve the students' English reading comprehension achievement. Moreover, Fitriyah (2018) developed English for Specific Academic Purposes (ESAP) materials using the principles of CTL approach for Islamic Education students at IAIN Kediri. A set of ESAP materials using the principles of CTL approach divided into 10 lessons was the product of her study. There were some sections and interactive tasks in each lesson. The result of her study showed that the students responded positively toward the developed materials. The developed materials were trustworthy and appropriate for the students. In addition, Amalia (2018) developed an English textbook for Islamic Primary Education Study 
Nurliana

Program students at KH. Abdul Chalim Institute. The product of her study was the English textbook for Islamic Primary Education Study Program students with its Islamic context. The result of her study showed that the textbook represents the context of Islamic Primary Education Study Program students. The students' positive responses showed the success of the textbook implementation. All of the relevant studies found and mentioned previously were only related to developing English materials using ESP approach for Islamic Education Study Program students and Islamic Primary Education Study Program students. The studies related to the materials development using ESP approach especially for al-Qur'an and Tafsir Study Program students were not found by the researcher. In other words, the studies related to the materials development for al-Qur'an and Tafsir Study Program students had not been conducted by other researchers. Thus, the findings of this study were expected to contribute meaningfully to the existing body of knowledge and the English teaching-learning process, especially for al-Qur'an and Tafsir Study Program at IAIN Palangka Raya.

\section{LITERATURE REVIEW}

\subsection{English for Specific Purposes (ESP) Approach}

The assumption underlying ESP approach was that the clear relevancy of English course to students' need would increase students' motivation in learning English. Thus, it makes learning which is better and faster (Hutchinson \& Waters, 1987). The experts of ESP approach, such as Hutchinson \& Waters (1987), Dudley-Evans \& St. John (1998) agreed that ESP approach can be classified into two categories. The first category is English for Academic Purposes (EAP). EAP is taught to students for academic study or understand specific subject domains, such as science \& technology, medicine, economics, and Islamic studies. The second category is English for Occupational Purposes (EOP). EOP is taught to students for professional/vocational/work support purposes. English of al-Qur'an and Tafsir at IAIN Palangka Raya can be classified as EAP, which is English for the specific field of academic study.

ESP approach has its characteristics which differentiate it from EGP approach. There are two categories of those characteristics, namely absolute characteristics and variable characteristics. The absolute characteristics of ESP approach are 1) It is designed to meet the students' specific need and 2) It centers on the language appropriate to the activities related to grammar, lexis, register, skills, discourse, and genre. The variable characteristics of ESP approach are 1) It can be designed for specific disciplines, 2) It can be used in a specific teaching situation, and 3) It is likely to be designed for intermediate or advanced level of language learning (Dudley-Evans \& St. John, 1998). The division of ESP characteristics is useful to differentiate what is categorized as ESP and what is not. 


\subsection{Materials}

The varied definitions have been put forward for materials. Tomlinson (2012: 143144) defined materials as anything used in the language teaching-learning process which includes textbooks, websites, videos, games, flashcards, grades readers, and also interactions of mobile phone. Moreover, Rüschoff \& Sudhoff (2018:2) referred materials as the components used in a classroom setting to initiate and encourage the specific learning objectives as stated in curriculum and lesson plans. Furthermore, Richards (2001:251) argued that materials commonly serves as the foundation for the language input which the students receive and the language practices which occur in class. Materials can be in the form of printed materials, non-printed materials, and materials in the form of both print and non-printed sources.

Good and effective materials can lead to the success of the English teaching-learning process Some principles of good materials proposed by Hutchinson \& Waters (1987:107-108) are 1) Providing a learning stimulus, 2) Helping to arrange the teaching-learning process, 3) Embodying a view of the language and learning nature, 4) Reflecting the learning task nature, 5) Introducing new techniques to teachers, and 6) Providing correct and appropriate language use models. The effective materials are formed by considering some factors. First, it is necessary to consider teacher factors which include the language proficiency of the teacher, training \& experience, cultural background, and style of teaching. Second, it is necessary to consider students' factors which include the preferred style of learning, needs of language learning, interests, and motivations. Last, it is necessary to consider contextual factors which include the culture of the school, conditions of the class, size of the class, and availability of the teaching resources in the situations where the English materials used (Richards, 2006:5-6).

\subsection{Materials Development}

Materials development is defined as the processes used by the practitioners in producing materials for the teaching-learning process of language (Tomlinson, 2012:13). There are various models of materials development. One of the models is proposed by Sugiyono (2013:298) which consists of the following steps:

1) Potency and problem

The study can be started from potency and problem. Data about potency and problem not only can be found by the researcher himself/herself but also can be based on other people's research reports, documentation of activity reports from individuals of certain institutions which are still up-to-date.

2) Data collection

After identifying the potency and problem, it is necessary to collect varied information. The collected information can be used as the basis of planning a certain product which is expected to solve the problem. 
Nurliana

3) Design of the product

The product design should be presented in the form of drawing, so it can be used as the guidance to evaluate and produce the product.

4) Validation of the Design

Validation of the product can be done by presenting some experienced experts to evaluate the new product designed. Each expert is asked to evaluate product design. Thus, the weakness and strengths of the product can be revealed.

5) Revision of the Design

After the product design is validated through discussion with the experts, the weaknesses can be revealed. The weaknesses are tried to be reduced by revising the design. The one revising the design is the researcher who develops the product.

6) Try-out of the product

In administration field or social field, for example, the new working system can be directly tried-out after being validated and revised. The first try-out is conducted by simulating the use of the working system. After being simulated, it can be tried-out on a limited group. The try-out is conducted to gather information about whether the new working system is more effective and efficient than the old system or another system.

7) Revision of the product

The researcher needs to check whether the product still has the weaknesses or not. If the weaknesses are still found, the revision is done.

8) Try-out of the product

The product can be applied in real condition for the broad scope. It is necessary to evaluate the weaknesses or obstacles which appear for further revision.

9) Revision of the product

Revision of the product is done if the weaknesses of the product are still found.

10) Mass production

Mass production is done if the tried-out product is effective and worth for mass production.

\section{RESEARCH METHODOLOGY}

The first semester students of al-Qur'an and Tafsir Study Program at IAIN Palangka Raya in academic year 2018/2019 were the subject of this study. There was only one class consisted of 25 students.

To gather the data needed in this study, the instruments used consisted of questionnaire, observation, and interview. The questionnaire was used as the instrument in need assessment, in expert validation, and at the end of the try-out. The explanation was as follows:

In need assessment, the questionnaire in the form of close-ended questions was used. The questionnaire was distributed to the first semester students of al-Qur'an and Tafsir Study Program at IAIN Palangka Raya in academic year 2018/2019. The 
purpose of the distributed questionnaire was to gather the data regarding the students' need for the developed materials. There were nine questions of the questionnaire. The questions were related to materials design, topics, skills, and exercises.

In expert validation, the questionnaire in the form close-ended and open-ended questions was used. The questionnaire was distributed to two experts. The purpose of the distributed questionnaire was to evaluate the draft as the basis of the revision. There were thirteen questions of the questionnaire supplemented with comment and suggestion section. The questions were related to the physical appearance, the organization of the materials, the instructional objectives, the topics, the grammar review, the examples, the exercises, the instructions, the coverage of the materials, the content of the materials, and the language of the materials.

At the end of the try-out, the questionnaire in the form of close-ended questions was used. The questionnaire was distributed to the first semester students of al-Qur'an and Tafsir Study Program at IAIN Palangka Raya in academic year 2018/2019. The purpose of the distributed questionnaire was to gather the data regarding the students' perception of the draft. There were five questions of the questionnaire related to the students' perception of the draft.

The observation was used during the try-out. The observation was used to gather the data needed regarding the appropriateness and applicability of the draft. The researcher as the key instrument observed the process of the try-out and noted down every relevant thing happened during the process. At the end of the try-out, the unstructured interview was done to some students of the first semester of al-Qur'an and Tafsir Study Program at IAIN Palangka Raya in academic year 2018/2019. The purpose of the interview was to gather the data regarding students' perception and suggestion of the draft as the basis of further revision.

Research and Development (R\&D) was considered appropriate to be used in this study. Latief (2016:186) explained that Educational R\&D is a research used in developing educational products. The developed educational products are textbooks, modules, media, syllabus, curriculum, media, and so forth. There were varied models of materials development using R\&D. In this study, the model of materials development proposed by Sugiyono (2013:298) was adapted.

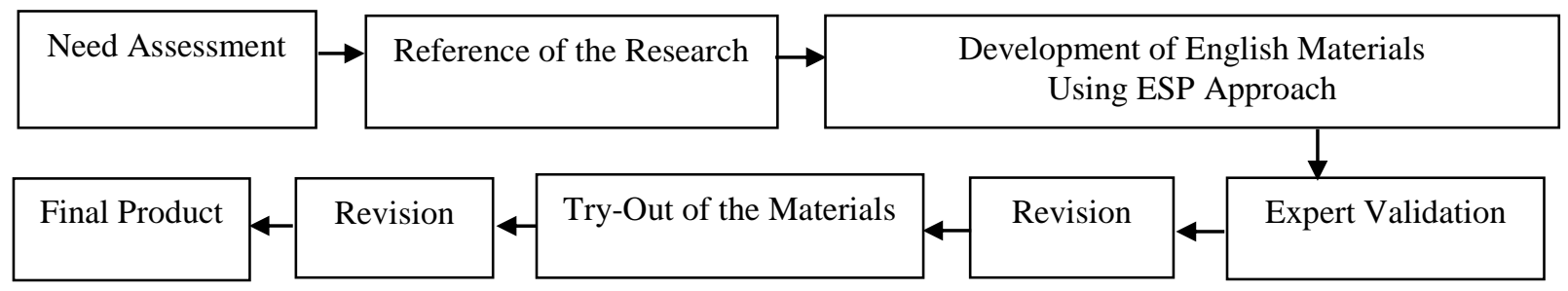

Figure: 1 The Procedure of the Study 


\section{Nurliana}

Need assessment was conducted to gather the data regarding the students' need for the developed materials. It was conducted by distributing the questionnaire to the first semester students of al-Qur'an and Tafsir Study Program at IAIN Palangka Raya in academic year 2018/2019. The result of the questionnaire was analyzed and converted by using the following formula:

$$
\mathrm{P}=\frac{\mathrm{n}}{\mathrm{N}} \times 100 \%
$$

in which:

$\mathrm{P}=$ Percentage

$\mathrm{n}=$ Number of students who prefer a certain option

$\mathrm{N}=$ Total number of students.

The result of the questionnaire was tabulated by using percentage. Every component was evaluated by using percentage. Thus, it was converted into qualitative data as follows: $100 \%$ (all), 90-99\% (most of), 80-89\% (a lot of), 50-79\% (many), 30-49\% (some), 1-29\% (few), and $0 \%$ (none). The result of the questionnaire in need assessment was used as the basis of developing the materials.

Reference of the research was done by exploring some theories about materials development and related studies as the basis of the development. It was done to develop the qualified English materials using ESP approach.

In the development of English materials using ESP approach, the first draft of the English materials using ESP approach for the first semester students of al-Qur'an and Tafsir Study Program at IAIN Palangka Raya in academic year 2018/2019 was developed. The materials were developed by considering the data gathered in need assessment. The researcher also considered the contents of the other courses in alQur'an and Tafsir Study Program as stated in the curriculum to be adapted in the developed English materials.

In expert validation, the experts evaluated the positive and negative points of the draft. It was conducted to gather the data regarding whether or not the draft had fulfilled the required criteria that had been set for this study. The data gathered by distributing the questionnaire to the experts. All data gathered was analyzed and described qualitatively

The revision was done by considering the data gathered in expert validation. In revision, the negative points found in the draft based on the result of expert validation were revised.

In the try-out of the materials, the researcher as the key instrument not only implemented the developed materials but also observed the process of the try-out and noted down every relevant thing happened during the process. At the end of the try-out, the questionnaire was distributed to the students to gather the data regarding the students' perception of the draft. The result of the questionnaire was analyzed and converted by using the following formula: 


$$
\mathrm{P}=\frac{\mathrm{n}}{\mathrm{N}} \times 100 \%
$$

in which:

$$
\mathrm{P}=\text { Percentage }
$$

$\mathrm{n}=$ Number of students who prefer a certain option

$\mathrm{N}=$ Total number of students.

The result of the questionnaire was tabulated by using percentage. The percentage was converted into qualitative data as follows: 100\% (all), 90-99\% (most of), 80$89 \%$ (a lot of), 50-79\% (many), 30-49\% (some), 1-29\% (few), and 0\% (none). After that, the interview was done to some students to gather data regarding the students' perception and suggestion of the draft. The data gathered in the interview was analyzed and described qualitatively.

The further revision was done after the developed materials had been tried out in the teaching-learning process. All data gathered from the try-out was used as the basis of the revision. Final product was the last step. At this step, the English materials using ESP approach for the first semester students of al-Qur'an and Tafsir Study at IAIN Palangka Raya was produced. The materials produced were in the form of a textbook.

\section{FINDINGS}

\subsection{The Result of Need Assessment}

The questionnaire was distributed to 25 students of the first semester of al-Qur'an and Tafsir Study program at IAIN Palangka Raya in academic year 2018/2019. The data gathered in need assessment was related to the students' need for materials design, topics, skills, and exercises of the developed materials. The data were presented in the tables below.

\begin{tabular}{|c|c|c|c|c|}
\hline $\begin{array}{c}\text { Item } \\
\text { Number }\end{array}$ & Question & Response & Number & Percentage \\
\hline \multirow[t]{2}{*}{1} & \multirow{2}{*}{$\begin{array}{l}\text { Should the developed } \\
\text { materials be interesting? }\end{array}$} & Yes & 25 & $100 \%$ \\
\hline & & No & 0 & $0 \%$ \\
\hline \multirow[t]{4}{*}{2} & \multirow{4}{*}{$\begin{array}{l}\text { According to you, the forms } \\
\text { of the illustration of the } \\
\text { materials which are } \\
\text { interesting are .... (allowed } \\
\text { to prefer more than one } \\
\text { option) }\end{array}$} & Colorful pictures & 25 & $100 \%$ \\
\hline & & Colorful photos & 25 & $100 \%$ \\
\hline & & Black and white pictures & 0 & $0 \%$ \\
\hline & & Black and white pictures & 0 & $0 \%$ \\
\hline \multirow[t]{2}{*}{3} & \multirow{2}{*}{$\begin{array}{l}\text { According to you, can the } \\
\text { pictures/photos help you } \\
\text { understand the explanation } \\
\text { and exercises given? }\end{array}$} & Yes & 25 & $100 \%$ \\
\hline & & No & 0 & $0 \%$ \\
\hline
\end{tabular}

Table: 1 Students' Need for the Materials Design

Indonesian Journal of EFL and Linguistics, 4(2), 2019 


\section{Nurliana}

Regarding the students' need for the materials design as presented in Table 1, all of the students stated that the developed materials should be interesting. For the interesting forms of the illustration of the materials, all of the students preferred colorful pictures and colorful photos. None of the students preferred black and white pictures, and none of the students preferred black and white photos. Moreover, all of the students stated that the pictures/photos could help them understand the explanation and exercises given.

Table: 2 Students' Need for the Topics

\begin{tabular}{clccc}
\hline $\begin{array}{c}\text { Item } \\
\text { Number }\end{array}$ & \multicolumn{1}{c}{ Question } & Response & Number & Percentage \\
\hline 4 & $\begin{array}{l}\text { Should the topics of the } \\
\text { developed materials be } \\
\text { interesting? }\end{array}$ & Yes & 25 & $100 \%$ \\
\hline 5 & $\begin{array}{l}\text { Would the materials be } \\
\text { interesting if the materials } \\
\text { are related to your field of } \\
\text { study? }\end{array}$ & Yes & 0 & $0 \%$ \\
\hline
\end{tabular}

Concerning the students' need for the topics of the developed materials as presented in Table 2, all of the students stated that the topics of the materials should be interesting. In addition, the students stated that the developed materials would be interesting if the materials were related to their field of study.

Table: 3 Students' Need for the Language Skills

\begin{tabular}{cllll}
\hline $\begin{array}{c}\text { Item } \\
\text { Number }\end{array}$ & \multicolumn{1}{c}{ Question } & Response & Number & Percentage \\
\hline 6 & $\begin{array}{l}\text { It is better if the language } \\
\text { skills (listening, speaking, } \\
\text { reading, and writing) are } \\
\text { taught .... }\end{array}$ & Integrated & 15 & $60 \%$ \\
\hline
\end{tabular}

Regarding the students' need for the language skills as presented in Table 3, many students stated that it was better if the language skills (listening, speaking, reading, and writing) were taught integrated, while only some students stated that it was better if the language skills were taught separately.

Table: 4 Students' Need for the Exercises

\begin{tabular}{clccc}
\hline $\begin{array}{c}\text { Item } \\
\text { Number }\end{array}$ & \multicolumn{1}{c}{ Question } & Response & Number & Percentage \\
\hline 7 & $\begin{array}{l}\text { Do you need the varied } \\
\text { forms of the exercises in } \\
\text { learning English? }\end{array}$ & Yes & 25 & $100 \%$ \\
8 & It is better if the exercises & Individually & 15 & $60 \%$
\end{tabular}


Developing English Materials Using ESP Approach

given are done ...
(allowed to choose more
than one option)
It is better if the exercises
given are in the form of
$\ldots$. (allowed to choose
more than one option)

$\begin{array}{ccc}\text { In pairs } & 13 & 52 \% \\ \text { In groups } & 17 & 68 \% \\ \text { Multiple-choice items } & 14 & 56 \% \\ \text { Essay } & 13 & 52 \% \\ \text { Fill in the blank items } & 14 & 56 \% \\ \text { Matching items } & 5 & 20 \% \\ \text { True/False Items } & 6 & 24 \%\end{array}$

Concerning the students' need for the exercises as presented in Table 4, all of the students stated that the varied forms of the exercises were needed in learning English. Furthermore, regarding how the exercises given were done, each option was preferred by many students. It was better if the exercises given were done individually, in pairs, and in groups. Regarding the form of the exercises, three options were preferred by many students. It was better if the exercises were given in the forms of multiple-choice items, essay, and fill in the blank items. Meanwhile, matching items and true/false items were preferred by only few students.

\subsection{Selection of the First Draft}

The first draft was developed based on the data gathered in need assessment. In developing the first draft, the researcher also adapted the contents of the other courses in al-Qur'an and Tafsir Study Program as stated in the curriculum. The researcher adapted the contents of Figh course, Tafsir Ayat Ahkam course, and Tafsir Ayat Sains course. The materials were developed for one semester consisted of eight units as follows.

- Unit 1 with the topic "Prayer"

- Unit 2 with the topic "Fasting"

- Unit 3 with the topic "Zakat"

- Unit 4 with the topic "Muamalat"

- Unit 5 with the topic "Food in Islamic Law"

- Unit 6 with the topic "Property Right in Islamic Law"

- Unit 7 with the topic "Inheritance in Islamic Law"

- Unit 8 with the topic "al-Qur'an and Science"

The contents of the draft in Unit 1 until Unit 4 were adapted from the contents of Fiqh course, the contents of the draft in Unit 5 until Unit 7 were adapted from the contents of Tafsir Ayat Ahkam course, and the contents of the draft in Unit 8 was adapted from the contents of Tafsir Ayat Sains course. The draft was also supplemented with a list of vocabularies section, a list of regular verbs section, and a list of irregular verbs section. 
Nurliana

\subsection{The Result of Expert Validation}

To evaluate the draft, the questionnaire was distributed to two experts. The first expert was the lecturer of University of Palangka Raya who was considered as an expert in English materials development and who had teaching experience for more than thirty-eight years. The second expert was the lecturer of IAIN Palangka Raya who had teaching experience for more than thirty-five years. The result of validation showed the positive and negative points of the draft.

\subsubsection{The Positive Points of the Draft}

The first-point evaluated by the experts was the cover design of the draft. Both experts agreed that the overall cover was interesting, the size of the fonts was appropriate, the size of the pictures was appropriate, and the selection of the colors was appropriate. The second-point evaluated was the fonts of the draft. Both experts agreed that the fonts were clear, appropriate, consistent, and readable. The thirdpoint was the typing of the draft. Both experts agreed that the typing was clear, neat, and readable. The fourth-point was the spacing of the draft. Both experts agreed that the spacing was appropriate and consistent. The fifth-point emerged from the layout of the draft. Both experts agreed that the overall display of the contents was interesting, the pictures used were interesting, the size of the pictures was appropriate, the arrangement of the texts and pictures was neat, the pictures used was relevant to the topics and contents of the draft, the selection of the colors was interesting, and the placement of the page numbers was consistent. The sixth-point evaluated was the organization of the draft. Both experts agreed that the draft was organized attractively, in order, and organized in the appropriate units. The seventhpoint was the topics of the draft. Both experts agreed that the topics were appropriate with the students' need and interest, appropriate with the students' field of study, varied, and up-to-date. The eight-point dealt with the grammar section of the draft. Both experts agreed that the grammar section was appropriate with the students' need and English language rules. The ninth-point evaluated was the examples used in the draft. Both experts agreed that the examples were clear and appropriate. The tenth-point was the exercises of the draft. Both experts agreed the exercises were appropriate with the given context, communicative, and could be done by the students. The eleventh-point was the instructions given in the draft. Both experts stated that the instructions were clear, appropriate, and understandable for the students. The twelfth-point was the contents of the draft. Both experts agreed that the contents were clear, appropriate with the students' field of study, appropriate with the students' need, understandable for the students, could increase the students' motivation, and could increase the students' English ability. The last-point evaluated was the use of language in the draft. Both experts agreed that the language used was appropriate with the students' level, understandable for the students, using correct spelling, using correct grammatical structures, and using appropriate diction. 


\subsubsection{The Negative Points of the draft}

The negative point of the draft based on the result of expert validation was concerning the size of the pictures used in the layout. One of the experts partly agreed that the size of the pictures in the layout of the draft was appropriate. The expert suggested making the size of the pictures smaller. Thus, the students would not be too focused only on the pictures.

\subsection{The Result of Try-Out}

The try-out was limited to four units: Unit 1 with the topic "Prayer", Unit 2 with the topic "Fasting", Unit 3 with the topic "Zakat", and Unit 4 with the topic "Muamalat". Each unit was tried in two meetings, so there were eight meetings of the try-out process. The try-out process was conducted to gather the data regarding the appropriateness and applicability of the developed materials as the basis of the revision. During the try-out, the researcher as the key instrument not only implemented the developed materials in the teaching-learning process but also observed the process of the try-out and noted down every relevant thing happened during the process. During the try-out process, there was an impression that the students responded positively toward the developed materials. The students were active, motivated, and enthusiastic in doing the activities of the developed materials. Since the materials were related to the students' field of study, the materials given could be easily understood. It seemed that the most interesting activity for the students was the presentation activity. In the presentation activity, the students could practice presenting the group paper in English. Based on the observation result, it could be inferred that the developed materials were applicable to the English teaching-learning process. At the end of the try-out, the questionnaire was distributed to 25 students of al-Qur'an and Tafsir Study Program to gather the data needed regarding the students' perception of the developed materials. The data were presented in the table below.

Table: 5 The Result of the Questionnaire at the End of the Try-Out

\begin{tabular}{|c|c|c|c|c|}
\hline \multirow{2}{*}{$\begin{array}{l}\text { Item } \\
\text { Number }\end{array}$} & \multirow[t]{2}{*}{ Question } & \multicolumn{3}{|c|}{ Response } \\
\hline & & Agree & $\begin{array}{l}\text { Partly } \\
\text { Agree }\end{array}$ & Disagree \\
\hline 1 & $\begin{array}{l}\text { The topics of the developed English materials } \\
\text { used in the teaching-learning process were } \\
\text { relevant to your field of study. }\end{array}$ & $100 \%$ & $0 \%$ & $0 \%$ \\
\hline 2 & $\begin{array}{l}\text { The developed English materials used in the } \\
\text { teaching-learning process were interesting for } \\
\text { you. }\end{array}$ & $100 \%$ & $0 \%$ & $0 \%$ \\
\hline 3 & $\begin{array}{l}\text { The developed English materials used in the } \\
\text { teaching-learning process could increase your } \\
\text { motivation to learn English }\end{array}$ & $100 \%$ & $0 \%$ & $0 \%$ \\
\hline
\end{tabular}

Indonesian Journal of EFL and Linguistics, 4(2), 2019 
Nurliana

The developed English materials used in the
teaching-learning process could make you active in the teaching-learning process.

$5 \quad$ As a whole, the developed English materials could be used well in the teaching-learning

$100 \% \quad 0 \% \quad 0 \%$ process.

The result of the questionnaire as presented in Table 5 showed that all of the students agreed that the topics of the developed English materials used in the teaching-learning process were relevant to their field of study. Moreover, the developed materials were interesting for them, could increase their motivation to learn English, and could make them active in the teaching-learning process. Furthermore, as a whole, the developed materials could be used well in the teachinglearning process.

The interview was also done to some students of al-Qur'an and Tafsir Study Program to gather the data needed regarding the students' perception and suggestion of the developed materials. Based on the result of the interview, it could be inferred that the developed materials were interesting for the students. The students became more active and enthusiastic in the teaching-learning process since the developed materials were related to their field of study. The most interesting activity of the developed materials according to the students was presenting the group paper in English. It was an unforgettable experience for them since in presenting the paper they could practice presenting the group paper related to some verses of the Holy Qur'an in English. It was the first time for them to have that kind of experience. The students thought that that kind of activity could increase their confidence in speaking English. Furthermore, the students suggested adding more vocabularies in a list of vocabularies section of the developed materials to enrich their knowledge of English vocabularies. All data gathered in the try-out was used as the basis of further revision.

\subsection{Final Product}

English materials using ESP approach in the form of a textbook for the first semester students of al-Qur'an and Tafsir Study Program at IAIN Palangka Raya in academic year 2018/2019 was the final product of this study. The textbook was divided into eight units with different topics as follows.

- Unit 1 with the topic "Prayer"

- Unit 2 with the topic "Fasting"

- Unit 3 with the topic "Zakat"

- Unit 4 with the topic "Muamalat"

- Unit 5 with the topic "Food in Islamic Law"

- Unit 6 with the topic "Property Right in Islamic Law" 
- Unit 7 with the topic "Inheritance in Islamic Law"

- Unit 8 with the topic "al-Qur'an and Science"

The textbook was also supplemented with a list of vocabularies section, a list of regular verbs section, and a list of irregular verbs section.

\section{DISCUSSION}

This research was conducted to develop English materials using ESP approach for the first semester students of al-Qur'an and Tafsir Study Program students in academic year 2018/2019. Thus, R\&D was used in this study. Based on the result of need assessment, English materials using ESP approach in the form of a textbook was developed. The model of materials development proposed by Sugiyono (2013:298) was adapted in this study.

The overall developed English materials using ESP approach were considered "Good" by the experts. One of the positive points evaluated by the experts was regarding the topics. The topics were appropriate with the students' need and interest, appropriate with the students' field of study, varied, and up-to-date. Another positive point was regarding the exercises. The exercises were appropriate with the given context, communicative, and could be done by the students. Moreover, the instructions given were clear, appropriate, and understandable for the students. Furthermore, the contents were clear, appropriate with the students' field of study, appropriate with the students' need, understandable for the students, could increase the students' motivation, and could increase the students' English ability. In addition, the language used was appropriate with the students' level, understandable for the students, using correct spelling, using correct grammatical structures, and using appropriate diction. It is in accordance with the opinion of Hutchinson \& Waters (1987:107) regarding the principles of good materials

The relevant studies (Rizal, 2017; Fitriyah, 2018; \& Amalia, 2018) showed that the students responded positively toward the developed English materials using ESP approach. The findings of this study also showed the students' positive response toward the developed English materials using ESP approach. Based on the result of observation during the try-out process, there was an impression that the students responded positively toward the developed materials. The students were active, motivated, and enthusiastic in doing the activities of the developed materials. Since the materials were related to the students' field of study, the materials given could be easily understood. Moreover, the result of the questionnaire distributed to the students showed that the developed materials were interesting for them, could increase their motivation to learn English, and could make them active in the teaching-learning process. Furthermore, the result of interview with some students showed that the developed materials were interesting for the students. The students became more active and enthusiastic in the teaching-learning process since the developed materials were related to their field of study. 
Nurliana

Basturkmen (2010) stated that ESP approach is set out to teach the skills of language and communication which specific groups of students need. Moreover, Hutchinson \& Waters (1987) stated that the standard way of achieving ESP approach is taking texts from students' specialist area, for example, text about Biology for Biology students, etc. The finding of this study in the form of English materials using ESP approach is developed in accordance with the theories of ESP approach proposed by Basturkmen (2010) and Hutchinson \& Waters (1987). The materials were developed based on the need of al-Qur'an and Tafsir Study Program students. Moreover, all of the texts of the developed materials were adapted from the texts of other courses in al-Qur'an and Tafsir Study Program as stated in the curriculum, namely Fiqh, Tafsir Ayat Ahkam, and Tafsir Ayat Sains. Thus, this finding of the developed materials using ESP approach might contribute to the English teaching-learning process particularly in the context of Al-Qur'an and Tafsir Study Program students.

\section{CONCLUSION}

English materials using ESP approach in the form of a textbook for the first semester of al-Qur'an and Tafsir Study Program at IAIN Palangka Raya in academic year 2018/2019 was the final product of this study. The product was developed by adapting Sugiyono's model (2013:298). Based on the findings of this study, the product was applicable to the English teaching-learning process and appropriate with the students' need. This study was expected to contribute meaningfully to the existing body of knowledge and the teaching-learning process of English of al-Qur'an and Tafsir Study Program at IAIN Palangka Raya.

\section{REFERENCES}

Amalia, E. R. (2018). Developing English Textbook Material for Islamic Primary Education Program: A Participatory Action Research. Alsuna: Journal of Arabic and English Language, 1(2), 69-77.

Basturkmen, H. 2010. Developing Courses in English for Specific Purposes. New York: Palgrave Macmillan.

Bracaj, M. M. (2014). Teaching English for Specific Purposes and Teacher Training. European Scientific Journal, 10(2), 1857-7881.

Dudley-Evans, T \& St John, M. J. (1998). Development in English for Specific Purposes. A Multi-Disciplinary Approach. Cambridge: CUP.

Fitriyah, I. (2018). Developing English Materials for Islamic Education Students of IAIN Kediri. Jurnal Bahasa Lingua Scientia, 10(1), 95-120. https://doi.org/10.21274/1s.2018.10.1.95-120

Hutchinson, T. \& Waters, A. (1987). English for Specific Purposes: A LearningCentered Approach. Cambridge: Cambridge University Press.

Hyland, K. (2019). English for Specific Purposes: Some Influences and Impacts. In Gao X. (eds) Second Handbook of English Language Teaching. Springer International Handbooks of Education. Springer, Cham. https://doi.org/10.1007/978-3-319-58542-0_19-1 
Latief, M. A. 2016. Research Methods on Language Learning: An Introduction. Malang: Malang State University.

Lee, B. (2015). EFL Learners Perspectives on ELT Materials Evaluation Relative to Learning Styles. RELC Journal, 46(2), 147-163. https://doi.org/10.1177/0033688214564177

Richards. J. C. (2001). Curriculum Development in Language Teaching. Cambridge: Cambridge University Press.

Richards, J. C. (2006). Materials Development and Research - Making the Connection. RELC Journal, 37(1), 5-26. https://doi.org/10.1177/0033688206063470

Rizal, S. (2017). Developing ESP Reading Comprehension Instructional Materials through Schema Theory Approach at PAI Study Program of Tarbiyah Faculty of IAIN Bengkulu. Paper presented at the $4^{\text {th }}$ UAD TEFL International Conference, Yogyakarta, Indonesia.

Rüschoff, B., \& Sudhoff, J. (2018). Teaching Aids and Materials. The TESOL Encyclopedia of English Language Teaching, 1-7. https://doi.org/10.1002/9781118784235.eelt0209

Sugiyono. 2013. Metode Penelitian Pendidikan. Pendekatan Kuantitatif, Kualitatif, dan $R \& D$. Bandung: Alfabeta.

Tomlinson, B. (2012). Materials Development for Language Learning and Teaching. Language Teaching, 45(2), 143-179. https://doi.org/10.1017/S0261444811000528 